\title{
Influence of bismuth on the microstructure, hardness and dry sliding wear behavior of magnesium silicide reinforced magnesium alloy composite
}

\author{
D.E. Umesha ${ }^{1}$, D. Shivalingappa ${ }^{2}$, R. Kishore $\mathrm{Kumar}^{2}$, Binto $\mathrm{Tomy}^{2}$, D. Ramesh Rao ${ }^{3}$ \\ ${ }^{1}$ Bapuji Institute of Engineering and Technology, Davangere-577004, India \\ ${ }^{2}$ Adhiyamaan College of Engineering, Hosur-635109, India \\ ${ }^{3}$ M.S. Ramaiah Institute of Technology, Bangalore-560099, India \\ dsivadvg@gmail.com, kishore.rg7@hotmail.com
}

PACS 06.20.-f 12.60.Rc 61.10.Nz

DOI 10.17586/2220-8054-2016-7-4-618-620

\begin{abstract}
The modification effect of bismuth $(\mathrm{Bi})$ on in-situ-formed magnesium silicide $\left(\mathrm{Mg}_{2} \mathrm{Si}\right)$ reinforced magnesium-aluminium (Mg- $\left.\mathrm{Al}\right)$ alloy is investigated using optical microscope, scanning electron microscope and X-ray diffraction. Processing of the in-situ composite was carried out through a stir casting technique. The size of $\mathrm{Mg}_{2} \mathrm{Si}$ is significantly refined and the optimal modification effect was obtained when the Bi content in the composite is $1.4 \%$. A slight decrease in hardness values and increase in wear resistance were observed in the study with bismuth addition.
\end{abstract}

Keywords: $\mathrm{Mg}-\mathrm{Al}$ Alloy, bismuth, modifier, in-situ composite, wear resistance.

Received: 3 February 2016

Revised: 4 April 2016

\section{Introduction}

Increasing the fuel efficiency of a vehicle is one of the main considerations in automotive field, which in turn, is directly influenced by the weight of the vehicle. Magnesium alloys and composites are the lightest structural materials which can be used extensively in automotive industries. Magnesium metal matrix composites can be processed using both ex-situ and in-situ techniques. However, it has been noted that the in-situ method of processing results in improved grain structure, mechanical properties and wear properties for the final metal matrix composites [1,2]. Magnesium alloys containing $\mathrm{Mg}_{2} \mathrm{Si}$ particles seem to show high melting temperatures, low density, high hardness, low thermal expansion coefficients and reasonably high elastic moduli. Uniform morphology of $\mathrm{Mg}_{2} \mathrm{Si}$ particles is difficult to obtain and moreover the size of these particles are larger in nature [3]. This can lead to poor mechanical properties for the composite. Modification is found to be a simple and effective technique for improving the morphology and size of $\mathrm{Mg}_{2} \mathrm{Si}$ particles in $\mathrm{Mg}-\mathrm{Al}$ alloys [4]. Modification of $\mathrm{Mg}_{2} \mathrm{Si}$ can be also done by adding additives such as $\mathrm{P}, \mathrm{Li}, \mathrm{Na}, \mathrm{KBF}, \mathrm{Ca}, \mathrm{La}$ [5-8] etc. Bismuth is found to be one of the suitable additives that can be used for the modification of $\mathrm{Mg}_{2} \mathrm{Si}$ particles.

The primary aim of the present study was to investigate the effect of Bi modification on the $\mathrm{Mg}_{2} \mathrm{Si}$ phase in $\mathrm{Mg}-\mathrm{Al}$ alloy. Based on these results, the hardness and dry sliding wear behavior of composites with different amounts of $\mathrm{Bi}$ were investigated.

\section{Experimental Procedures}

\subsection{Materials and Processing}

Commercially pure Mg ingot (99.3\% purity), Al ingot (99.2\% purity) and Si powder (99.9\% purity) were used as the starting materials to prepare the $\mathrm{Mg}-\mathrm{Al} / \mathrm{Mg}_{2} \mathrm{Si}$ composites. The melting process was carried out in a steel crucible kept in a $2 \mathrm{~kW}$ electric resistance furnace under a protective atmosphere of argon gas. The furnace had a bottom pouring configuration and was also provided with an inert gas atmosphere.

The processing of composites was carried out in two stages by a stir casting technique. In the first stage, cast aluminium-silicon master alloy was synthesized by dispersing silicon particles into the molten aluminium. In the second stage, cast $\mathrm{Al}-\mathrm{Si}$ master alloy was dissolved in the molten magnesium $\left(760{ }^{\circ} \mathrm{C}\right)$ in such amounts so that the final mixture had $9 \mathrm{wt} \% \mathrm{Al}$ in $\mathrm{Mg}-\mathrm{Al}$ matrix alloy and $2.5 \mathrm{wt} \% \mathrm{Mg}_{2} \mathrm{Si}$ reinforcement. For refinement of $\mathrm{Mg}_{2} \mathrm{Si}$ bismuth $(0,0.7,1.4,2 \mathrm{wt} \%)$ was added to the molten magnesium. Stirring was done at $600 \mathrm{rpm}$ for 10 minutes for all samples. Finally, the composite slurry was poured into a $30 \mathrm{~mm} \times 50 \mathrm{~mm} \times 120 \mathrm{~mm}$ steel mold. 


\subsection{Materials characterization and phase analysis}

XRD analysis was carried out for powders from $\mathrm{Mg}-\mathrm{Al} / \mathrm{Mg}_{2} \mathrm{Si}$ composite containing $1.4 \mathrm{wt} \% \mathrm{Bi}$ and $\mathrm{Mg}-\mathrm{Al} /$ $\mathrm{Mg}_{2} \mathrm{Si}$ composite without $\mathrm{Bi}$. Specimens for microstructure analysis were prepared using standard procedures and optical microscopy and SEM examination and EDS analysis were carried out.

\subsection{Hardness and wear tests}

The Brinell hardness test was used to measure the hardness of the specimens. Test specimens were indented with a $5 \mathrm{~mm}$ diameter hardened steel ball subjected to a load of $150 \mathrm{~N}$ applied for 10 seconds. Dry sliding wear tests were conducted according to the ASTM G99 standard using pin-on-disc machine. The wear tests for all specimens were conducted under two different loads $(10 \mathrm{~N}$ and $20 \mathrm{~N})$ and varying the disc rotating speeds of 300 , 350, 400 and $450 \mathrm{rpm}$. Wear tests were carried out for a total sliding distance of approximately $1000 \mathrm{~m}$. The pin samples were $30 \mathrm{~mm}$ in length and $8 \mathrm{~mm}$ in diameter.

\section{Results and Discussion}

\subsection{Microstructural features}

Figure 1 shows the XRD patterns of $\mathrm{Mg}-\mathrm{Al} / \mathrm{Mg}_{2} \mathrm{Si}$ composite without Bi content and with 1.4 wt. \% Bi content respectively. The XRD pattern reveals that the processed in-situ composite contains $\alpha-\mathrm{Mg}, \beta-\mathrm{Al}_{12} \mathrm{Mg}_{17}$ and $\mathrm{Mg}_{2} \mathrm{Si}$ phases. Some new peaks appear in the pattern with the addition of $1.4 \mathrm{wt} . \% \mathrm{Bi}$. The XRD pattern of the in-situ composite which was processed with the bismuth refinement material confirmed the presence of bismuth by showing the additional peaks corresponding to it.

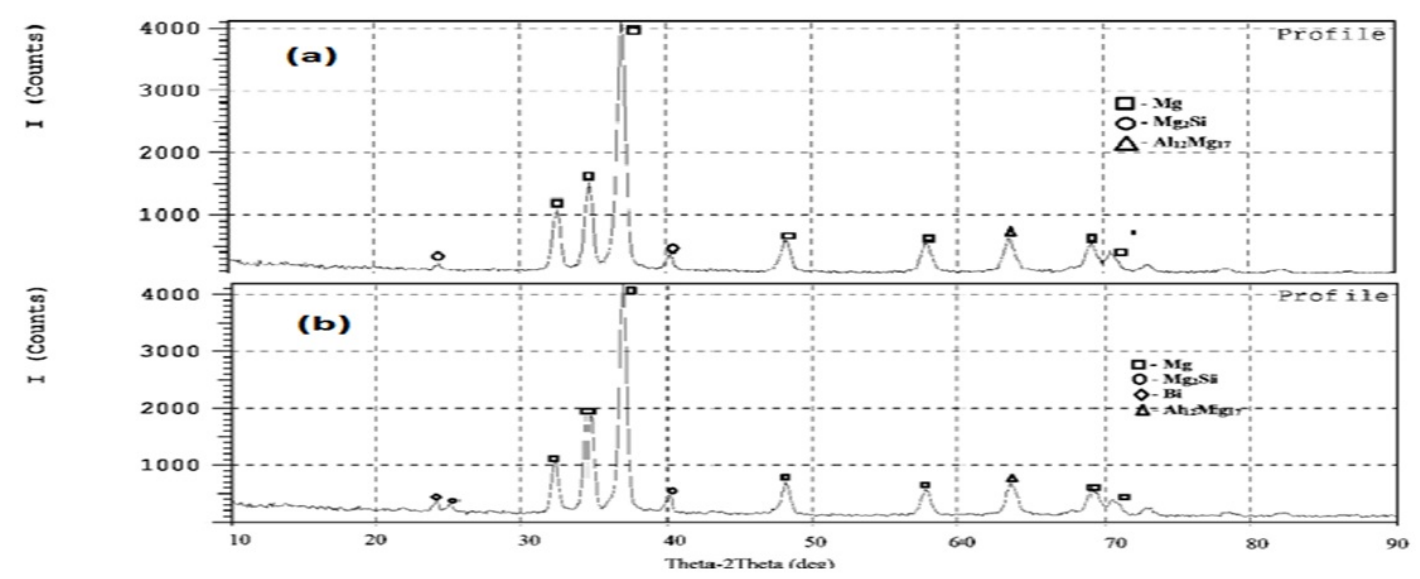

FIG. 1. XRD pattern of $\mathrm{Mg}-\mathrm{Al} / \mathrm{Mg}_{2} \mathrm{Si}$ composite (a) $0 \mathrm{wt} \%$ (b) $1.4 \mathrm{wt} \% \mathrm{Bi}$

The SEM micrographs, along with EDS patterns for in-situ composite with and without bismuth are shown in Figs. 2(a) and 2(b) respectively. The presence of bismuth was confirmed from the additional peaks, as is seen in Fig. 2(b) compared to peaks in Fig. 2(a). The larger size of the reinforcing $\mathrm{Mg}_{2} \mathrm{Si}$ particles can be seen in the Fig. 2(a), whereas refined and smaller size of $\mathrm{Mg}_{2} \mathrm{Si}$ phase can be seen in Fig. 2(b). Small white spots in Fig. 2(b) correspond to bismuth powder. The $\mathrm{Mg}_{2} \mathrm{Si}$ particles in an unmodified sample were found to be clustered throughout as large particles.

The morphology was poor when compared to the $2 \%$ Bismuth modified specimen. As the percentage of bismuth increased, the $\mathrm{Mg}_{2} \mathrm{Si}$ particles became divided, finally resulting in a unique particle distribution. However, it is also readily seen that the particles became coarser with more addition of bismuth.

\subsection{Hardness and wear tests}

Hardness tests revealed that $\mathrm{Bi}$ decreases the hardness value of the composites; however its variation is limited. The $\mathrm{Mg}-\mathrm{Al} / \mathrm{Mg}_{2} \mathrm{Si}$ composite showed better hardness properties than those $\mathrm{Mg}-\mathrm{Al} / \mathrm{Mg}_{2} \mathrm{Si}$ composites which were modified by varying amounts of bismuth. The hardness graph of the composite $\left(\mathrm{Mg}-\mathrm{Al} / \mathrm{Mg}_{2} \mathrm{Si}\right)$ with varying bismuth content is shown in Table 1.

Figure 3 shows the variation of wear rate for $\mathrm{Mg}-\mathrm{Al} / \mathrm{Mg}_{2} \mathrm{Si}$ composite with $\mathrm{Bi}$ content. A decrease in wear rate can be seen with an increased $\mathrm{Bi}$ content and speed. However, the variation of decrease for wear rate can be seen more at higher loads $(20 \mathrm{~N})$. 

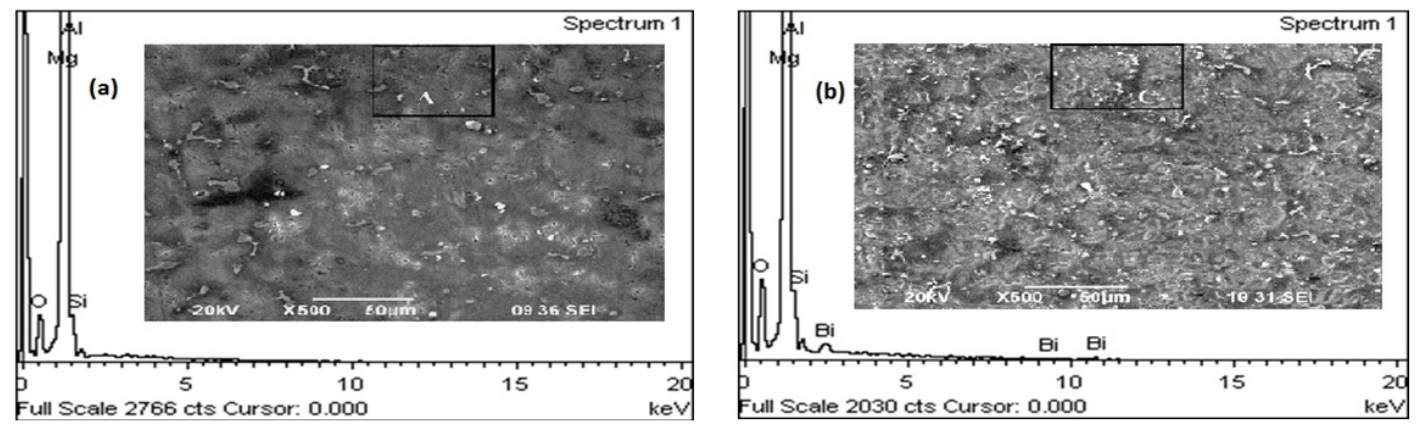

FIG. 2. SEM images with EDS of $\mathrm{Mg}-\mathrm{Al} / \mathrm{Mg}_{2} \mathrm{Si}$ (a)without and (b)with $1.4 \mathrm{wt} \% \mathrm{Bi}$

TABLE 1. Variation of hardness of $\mathrm{Mg}-\mathrm{Al} / \mathrm{Mg}_{2} \mathrm{Si}$ composite with Bi content

\begin{tabular}{|c|r|r|r|r|}
\hline Bismuth (wt\%) & 0 & 0.7 & 1.4 & 2 \\
\hline Hardness (BHN) & 72.9 & 69.3 & 69.3 & 71.5 \\
\hline
\end{tabular}
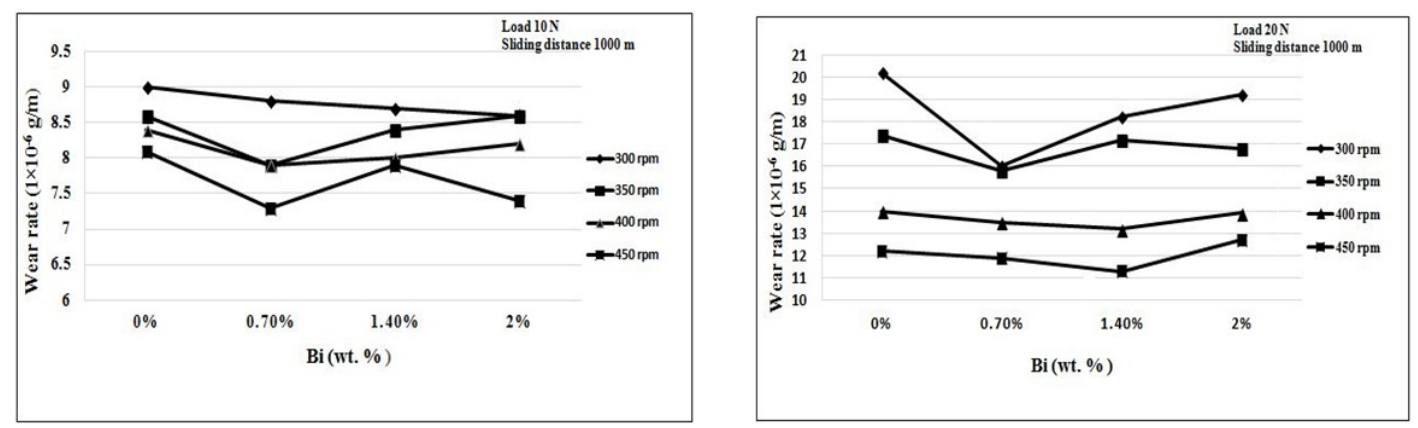

FIG. 3. Variation of wear rate of $\mathrm{Mg}-\mathrm{Al} / \mathrm{Mg}_{2} \mathrm{Si}$ composite with Bi content

\section{Conclusion}

From the research, it can be indentified that bismuth plays a significant role in modifying the morphology of $\mathrm{Mg}_{2} \mathrm{Si}$ particles in $\mathrm{Mg}-\mathrm{Al} / \mathrm{Mg}_{2} \mathrm{Si}$ composite. The size of the $\mathrm{Mg}_{2} \mathrm{Si}$ particles and the hardness values decreased with the addition of bismuth (Bi). However, it was shown that $\mathrm{Bi}$ exerts a great influence on wear resistance, as that property was enhanced with increased bismuth content.

\section{References}

[1] Bhingole P.P., Chaudhari G.P., Nath S.K. Processing, microstructure and properties of ultrasonically processed in situ $\mathrm{MgO}_{-} \mathrm{Al}_{2} \mathrm{O}_{3}-$ $\mathrm{MgAl}_{2} \mathrm{O}_{4}$ dispersed magnesium alloy composites. Compos. Part A Appl. Sci. Manuf., 2014, 66, P. 209-217.

[2] Shivalingappa D., Daniel B.S.S., Ray S. Effect of reinforcing phase inherited from another composite on the mechanical properties of cast magnesium base composite. Mater. Sci. Eng. A, 2012, 541, P. 172-180.

[3] Hu Y., Rao L. Effect of particulate reinforcement on wear behavior of magnesium matrix composites. Trans. Nonferrous Met. Soc. China, 2012, 22, P. 2659-2664.

[4] Hu J., Tang C., Zhang X., Deng Y. Modification of $\mathrm{Mg}_{2} \mathrm{Si}$ in $\mathrm{Mg}-\mathrm{Si}$ alloys with neodymium. Trans. Nonferrous Met. Soc. China, 2013, 23, P. 3161-3166.

[5] Tang S., Zhou J., Tian C., Yang Y. Morphology modification of $\mathrm{Mg}_{2} \mathrm{Si}$ by Sr addition in $\mathrm{Mg}-4 \% \mathrm{Si}$ alloy. Trans. Nonferrous Met. Soc. China, 2011, 21, P. 1932-1936.

[6] Qin Q.D., Zhao Y.G., Zhou W., Cong P.J. Effect of phosphorus on microstructure and growth manner of primary $\mathrm{Mg}_{2} \mathrm{Si}$ crystal in $\mathrm{Mg}_{2} \mathrm{Si} / \mathrm{Al}$ composite. Mater. Sci. Eng. A, 2007, 447, P. 186-191.

[7] Hadian R., Emamy M., Varahram N., Nemati N. The effect of Li on the tensile properties of cast $\mathrm{Al}-\mathrm{Mg}_{2} \mathrm{Si}$ metal matrix composite. Mater. Sci. Eng. A, 2008, 490, P. 250-257.

[8] Emamy M., Khorshidi R., Raouf A.H. The influence of pure Na on the microstructure and tensile properties of Al- $\mathrm{Mg}_{2} \mathrm{Si}$ metal matrix composite. Mater. Sci. Eng. A, 2011, 528, P. 4337-4342. 